\title{
An evaluation of SAARC in the regional development of South Asia
}

\author{
Manoj Srivastava \\ orcid.org/0000-0001-5433-0935 \\ Research Fellow, Indira Gandhi National Open University, Maidan Garhi, New Delhi.
}

\begin{abstract}
:
South Asia Association for Regional Cooperation (SAARC) has been seen as a regional group for the economic and social growth in the South Asia since its formation by South Asian founding nations. There have been various conceptualized goals and objectives for the SAARC. Some of these performed to the satisfaction of group nations whereas there are those one also which could not be achieved despite common understanding and implementation. This paper evaluates the performance of the regional group as to its justification for the social \& economics growth driver in the South Asia region.
\end{abstract}

KEYWORDS: SAARC, South Asia, economic and social growth in South Asia, Success of SAARC in South Asia.

\section{INTRODUCTION:}

SAARC

The South Asian Association for Regional Cooperation (SAARC) is a monetary and geopolitical association of eight nations that are essentially situated in South Asia or the Indian subcontinent. The SAARC Secretariat is situated in Kathmandu, Nepal. The consolidated economy of SAARC is the third biggest on the planet in the terms of GDP(PPP) after the United States and China and fifth biggest in the terms of ostensible GDP. SAARC countries involve 3\% of the world's territory and contain $21 \%$ (around 1.7 billion) of the world's aggregate populace and around 9.12\% of Global economy starting 2015. SAARC additionally home to world's third and seventh biggest Economy of world in GPP(PPP) and GDP(Nominal) terms separately and in addition World's quickest developing real Economy, that is India. India makes up more than $70 \%$ of the region and populace among these eight countries. Amid 2005-10, the normal GDP development rate of SAARC remained at a noteworthy $8.8 \%$ p.a., however it eased back to $6.5 \%$ in 2011 to a great extent in view of financial lull in India, which represents almost $80 \%$ of SAARC's economy. In any case, driven by an in number extension in India, combined with ideal oil costs, from the last quarter of 2014 South Asia by and by turn into the quickest developing area on the planet. Starting 2015, outside trade stores of SAARC countries remains at USD 411 billion.

The thought of provincial political and temperate participation in South Asia was initially brought up in 2 May 1980 by Bangladesh President Ziaur Rahman and the first summit was held in Dhaka on 8 
December 1985, when the association was set up by the legislatures of Bangladesh, Bhutan, India, Maldives, Nepal, Pakistan, and Sri Lanka. From that point forward the association has extended by tolerating one new full part, Afghanistan, and a few eyewitness individuals.

The SAARC arrangements plan to advance welfare financial aspects, aggregate confidence among the nations of South Asia, and to quicken socio-social improvement in the locale. The SAARC has created outside relations by setting up changeless strategic relations with the EU, the UN (as an eyewitness), and other multilateral elements. The official gatherings of the pioneers of every country are held yearly whilst the remote pastors meet twice every year. The eighteenth SAARC Summit was held in Kathmandu from 26-27 November 2014.

SAARC's structure is based upon an establishment of an in number arrangement of targets. Each choice SAARC takes and each strategy it casings is guided by the general targets it had set for itself in the contract. In spite of the fact that advancing "welfare financial matters" and "aggregate independence" among the South Asian countries are the normally cited destinations, yet there are some similarly essential center regions which require a notice. "Quickening financial development" and social advancement in South Asia is one of the needs, which go under the more extensive objective of enhancing personal satisfaction.

Giving each individual the "chance to live in respect and to understand their true abilities" additionally discovers a spot in the rundown of destinations. "Comprehension and energy about each other's issues" is one of the uncommon destinations that one finds in any local gathering. SAARC likewise looks for coordinated effort in the field of financial aspects, society, innovation and science. The part nations intend to fortify "participation among themselves in worldwide gatherings on matters of normal hobbies."

\section{SAARC RECOGNIZED BODIES}

As an association, SAARC fundamentally works through six zenith bodies which guarantee territorial collaboration on various levels:

SAARC Chamber of Commerce and Industry $(\mathrm{SCCl})$ : The element empowers intra-territorial exchange by making business linkages among the business people. Its essential center is on the all encompassing development of administration part and little and medium undertakings.

SAARCLAW (South Asian Association for Regional Cooperation in Law): The yearning to set up a relationship inside of the SAARC locale "to disperse data" and "advance a comprehension of the worries and improvements" provoked the conception of SAARCLAW in 1991. This relationship of lawful groups of SAARC countries was set up in Colombo.

South Asian Federation of Accountants (SAFA): In 1984, this association appeared with a target of fortifying and serving the bookkeeping calling in the South Asian Region.

South Asia Foundation (SAF): A non-benefit and non-political association established by UNESCO Goodwill Ambassador Madanjeet Singh in 2000, SAF energizes territorial participation through UNESCO Madanjeet Singh Institutions of Excellence. The foundations offer courses on fluctuated subjects going from Climate and Green Energy to Human Rights and Visual Arts.

South Asia Initiative to End Violence Against Children (SAIEVAC): Founded in 2005, this provincial gathering goes for "completion all types of savagery against kids in South Asia." 
Establishment of SAARC Writers and Literature (FOSWAL): It's the first non-government association working towards sustaining and reinforcing social network through cooperations among SAARC countries.

\section{SAFTA}

In a historic point move, SAARC countries collectively chose to frame South Asian Free Trade Area (SAFTA). Despite the fact that the assention was come to at the twelfth SAARC summit in 2004, it came into power on 1 January 2006. The assention not just made an unhindered commerce territory of 1.8 billion individuals in SAARC countries (aside from Afghanistan), additionally evacuated exchange obstructions to expand the level of monetary collaboration.

\section{SAARC SECRETARIAT}

The SAARC Secretariat in Kathmandu (Nepal) encourages and screens usage of exercises of the association and goes about as a correspondence channel in the middle of SAARC and its part states. In no time, the Secretariat is going by Nepal's ex-outside secretary - Arjun Bahadur Thapa.

\section{ACCOMPLISHMENTS AND CRITICISM OF SAARC}

As indicated by the statement of the 16thSAARC Summit (April 2010), SAARC's "degree and substance of collaboration had extended to various fields." The SAARC Summits have for sure made a stage for shut entryway two-sided talks restrictive to the taking an interest countries. These gatherings have fairly prompted the advancement in local collaboration.

The extent of provincial participation in SAARC has multiplied, and it has begun to draw in political, financial, social, social and different viewpoints in its dialog. Indeed, even the part countries' collaborations with the Chambers of Commerce and Industry and the corporate areas appear to be growing step by step. Be that as it may, SAARC is seen as a disappointment by numerous experts. As indicated by eyewitnesses, it has "accomplished next to no" in the course of the most recent three decades. Other than falling apart local security environment and development of terrorism in Pakistan and Afghanistan, between state question are additionally a bothering sympathy toward the gathering. Social and financial divisions have enrolled a dreary development, as is the intra-provincial exchange.

\section{CONCLUSION:}

SAARC frets about the issues of independence, destruction of neediness, ignorance, ailing health and infection in the territory. Surely, in none of the regions has the effect of SAARC been obvious. While some helpful assentions have been marked amid past SAARC summits, their execution has failed to impress anyone. The exchange assention, South Asian Free Trade Area (SAFTA), is an a valid example. Why has SAARC not been fruitful in fashioning better and more important relations with each other? Not at all like the European Union, or ASEAN, individuals from SAARC are not equivalent accomplices on account of the unequal size of their economies. Political pressures in the middle of India and Pakistan are another purpose behind the association not being fruitful. The third reason is that part nations take a gander at exchange concurrences with a nearsighted viewpoint and restricted national hobbies. Pakistan has still not allowed India the Most Favored Nation (MFN) status because of residential impulses. Intra-territorial exchange products in the SAARC area stays around five percent and, in administrations, scarcely 0.2 percent against 26 percent in ASEAN. The 
fourth reason could be ascribed to absence of network between distinctive SAARC nations. India's exchange with Afghanistan is hampered on account of the common pressures in the middle of India and Pakistan. Essentially, Pakistan's exchange with Bangladesh and Nepal relies on upon its great relations with India. The absence of security and terrorist dangers in most SAARC nations are more blocks. On the off chance that the above concerns are to be surmounted, India ought to assume a vital part by evacuating the apparent doubt and feeling of unreliability among the part countries. As a matter of first importance, it needs to concentrate on enhancing reciprocal ties with Pakistan for better collaboration and exchange between the two nations, which can convey thriving to the general population on both sides of the gap. Pakistan, then again, ought to give MNF status to India and enhance street and rail network between India, Pakistan and Afghanistan for the development of products between these three nations. Both India and Pakistan can assume a huge part in battling terrorism. They can likewise assume a significant part in enhancing the economies of littler nations like the Maldives, Bhutan and Nepal by investing so as to expand imports from these nations, in their infrastructural offices and enhancing exchange between all SAARC nations. The participation between individuals will give a fillip to SAARC to assist it with understanding its goal of giving each individual the "chance to live in poise and to understand their maximum capacity". SAARC can likewise assume an essential part in empowering joint effort in the fields of financial aspects, society, innovation and science. In any case, this is conceivable just when India and Pakistan enhance their reciprocal relations, a sine qua non for the accomplishment of SAARC.

\section{REFERENCES:}

Chowdhury, M. B. (2005). Trade reforms and economic integration in South Asia: SAARC to SAPTA. Applied Econometrics and International Development, 5(4).

Dubey, M. (2007). SAARC and South Asian economic integration. Economic and Political Weekly, 1238-1240.

Hassan, M. K. (2001). Is SAARC a viable economic block? Evidence from gravity model. Journal of Asian Economics, 12(2), 263-290.

Jetly, R. (2003). Conflict management strategies in ASEAN: perspectives for SAARC. The Pacific Review, 16(1), 53-76.

Secretariat, S. A. A. R. C. (2010). SAARC Regional Energy Trade Study (SRETS). Kathmandu, Nepal, March.

Taneja, N. (2001). Informal trade in SAARC region. Economic and Political Weekly, 959-964. 